DOI: 10.15393/j10.art.2019.4081

УДК 930.25, 17.81.31

Марина Владимировна Заваркина

(Петрозаводск, Российская Федерация)

dostoyevsky@mail.ru

\title{
Проблемы хронояогической атрибуции «второй» записной книжки Ф. М. Достоевского
}

Аннотация. В статье предпринята попытка хронологической атрибуции «второй» записной книжки Ф. М. Достоевского, хранящейся в фонде ОР РГБ (93.I.2.7). Рассматриваются все возможные датировки ведения книжки в целом и отдельных записей в частности. Так как книжка заполнялась в разных направлениях, порой хаотично, сложно установить точный хронологический порядок ведения записей. В статье делается вывод, что однозначно следует отказаться от датировки «1861-1864», указанной в некоторых изданиях. Рассматривается возможность ведения книжки в последние месяцы 1862 г., однако предложенный Г. М. Фридлендером период «1862-1864» нуждается в дополнительном обосновании. Чтобы понять последовательность заполнения книжки, в статье сгруппированы и проанализированы записи, относящиеся к 1863 и к 1864 гг.: именно в это время Достоевский чаще всего обращался к записной книжке. Многие вопросы, затрагиваемые в статье, носят дискуссионный характер и требуют дальнейшей разработки.

Ключевые слова: Ф. М. Достоевский, рукописи, записные книжки и тетради, текстология, атрибуция, датировки

Об авторе: Заваркина Марина Владимировна - кандидат филологических наук, учитель русского языка и литературы, Первая частная школа (185 001, Российская Федерация, Республика Карелия, г. Петрозаводск, Мурманская, 28)

Дата поступления: 01.05.2019

Дата публикации: 30.06.2019

Для цитирования: Заваркина М. В. Проблемы хронологической атрибуции «второй» записной книжки Ф. М. Достоевского // Неизвестный Достоевский. - 2019. - № 2. - C. 5-39. DOI: 10.15393/j10.art.2019.4081

$\left\{\begin{array}{l}\text { аписная книжка под условной нумерацией «№ 2» (далее } \\ 3 K_{2} \text { ), хранящаяся в Отделе рукописей Российской госу- }\end{array}\right.$ дарственной библиотеки (Ф. 93.I.2.7), содержит записи литературного, литературно-критического и автобиографического характера, записи, связанные с редакторской и издательской 
деятельностью Ф. М. Достоевского, заметки для памяти, деловые, хозяйственные записи и расчеты. Набросков к художественным произведениям в $3 K_{2}$ немного: писатель продолжает переделку повести «Двойник», а также делает небольшой набросок к роману «Пьяненькие» (будущее «Преступление и Наказание»). Достоевский ведет разработку литературнокритических статей, полемику с «Современником» (раньше объектами полемики были Чернышевский и Добролюбов, теперь - Салтыков-Щедрин и Антонович), делает наброски к неосуществленной статье «Социализм и христианство» (развиты в одной из следующих записных тетрадей). Бо́льшая часть $3 K_{2}$ - это записи, связанные с редакторской деятельностью Достоевского в журналах «Время» и «Эпоха» (списки авторов, перечни статей, расчеты). Важное место занимают записи биографического характера, вызванные смертью родных людей: первой жены, Марии Дмитриевны, и брата, Михаила Михайловича. По верному замечанию Л. М. Розенблюм, этот «дневник “для себя”, не теряя своей непосредственности и искренности, мог стать и дневником “для других”. Таких примеров больше в тетрадях 70-х годов, когда Достоевский поставил перед собой новую, оригинальную творческую задачу создания “Дневника писателя"<...> Для Достоевского записи в тетрадях - важнейшее звено творческого процесса, а сама тетрадь - единственное место, куда помещаются дневниковые записи» [Розенблюм: 10-11].

$3 K_{2}$ имеет несколько предположительных датировок в исследовательской литературе. В «Описании рукописей...» В. С. Нечаевой (1957) была принята общая датировка «1862-1864» [Нечаева, 1957: 132, 139, 296, 313], отдельные записи датируются 1864 г. [Нечаева, 1957: 273-274]. Однако на стр. 286 и 291 появляется датировка «1863-1864». При первой публикации $3 K_{2}$ в 1971 г. в 83 томе «Литературного наследства» (далее ЛН) также допущено расхождение. Во вступительной статье Г. М. Фридлендера указана датировка «1862-1864» [Фридлендер: 103], а в примечании уточняется: «Начало датировки установлено по содержанию записей» [Фридлендер: 122]. Однако в самой публикации книжки, выполненной Л. Р. Ланским и С. С. Борщевским, стоит другая датировка: «1863-1864» 
[ЛН, т. 83: 171]. При републикации $3 K_{2}$ в 1980 г. в 20 томе академического Полного собрания сочинений Ф. М. Достоевского оставлена датировка «1863-1864» (Д30; 20: 170, 360), однако в 7 томе встречаем еще одну: «1861-1864» (Д30; 7: 309). В первом томе «Летописи жизни и творчества Ф. М. Достоевского» указаны две разные датировки: «1863-1864» [Летопись: 389] и «1861-1864» [Летопись: 498]. В Полном собрании сочинений в авторской орфографии и пунктуации ${ }^{2}$ (Ө. Д.; VI: 697) и в Полном собрании сочинений и писем в 35 томах $^{3}$ (Д35; 1: 700) датировка $3 K_{2}$ находится под вопросом: «1862-1864?».

Сложность хронологической атрибуции данной записной книжки заключается в том, что восстановить порядок ведения записей не представляется возможным. Во-первых, $3 K_{2}$ заполнялась, скорее всего, в направлении, обратном общей нумерации, во-вторых, многие записи заносились одновременно (окончательный вид они принимали позже в других рабочих тетрадях), что связано с особенностями ведения Достоевским своих записных книжек и тетрадей (см.: Д30; 20: 360). В статье «От редакции», предваряющей первую публикацию книжки, сказано: «Известно, что писатель заполнял тетради не подряд. Он мог открыть любую страницу, иногда частично исписанную, чтобы торопливо зафиксировать на ней новые мысли и образы. Нередко он переворачивал страницы слева направо, открывал тетрадь с обратной стороны и писал некоторое время в порядке, противоположном принятому ранее, а потом вновь переходил к началу тетради или к любой случайной странице другой тетради» [ЛН, т. 83: 6]. По мнению В. Н. Захарова, «внешне записи производят впечатление хаоса и беспорядка, но они создавались в своей, понятной писателю логике» [Захаров, 2018: 93].

На заднем форзаце $3 K_{2}$, в правом верхнем углу, была обнаружена угасшая запись.

Напомним, что при расшифровке «первой» $3 K$ (далее $3 K_{1}$ ) запись в правом верхнем углу переднего форзаца была прочитана нами вслед за публикаторами ЛН и Д30 как «4 я<нваря> 60» [ЛН, т. 83: 125], (Д30; 20: 346), [Заваркина: 71-74]. 
Аналогичная запись на заднем форзаце $3 K_{2}$ была также сначала прочитана как дата (см.: Илл. 1-3).

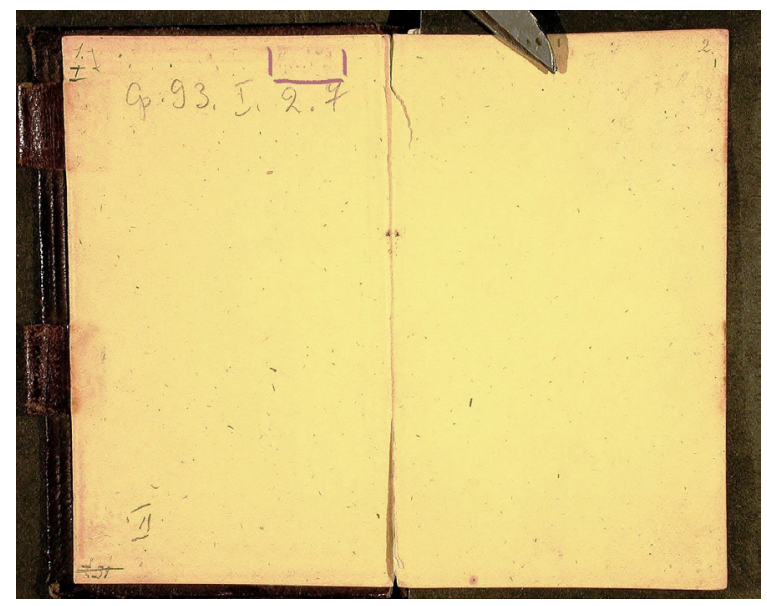

Илл. 1. Задний форзац $3 K_{2}$

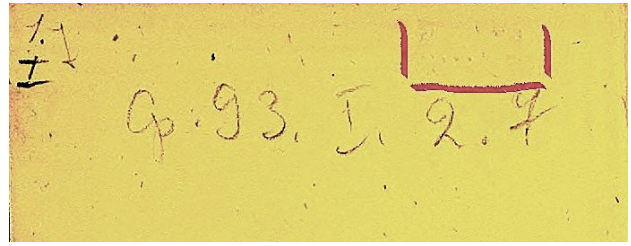

Илл. 2. Фрагмент заднего форзаца $3 K_{2}$

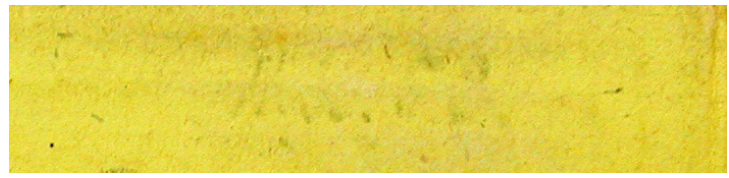

Илл. 3. Более детальный фрагмент заднего форзаца $3 K_{2}$

Позже подобные записи были обнаружены и в других рукописях Достоевского. И. С. Андрианова предположила, что записи в $3 K_{1}$ и $3 K_{2}$ являются пометами («Н. Я.» и номер), сделанными либо архивистами, либо А. Г. Достоевской (см.: Илл. 4-5). 


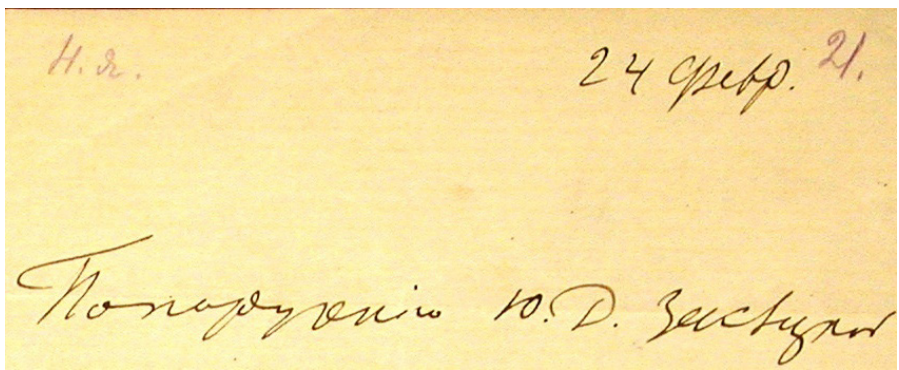

Илл. 4. Фрагмент записки В. Ф. Пуцыковича Ф. М. Достоевскому от 24 февраля [1874 г.]. (ОР РГБ. Ф. 93.І.3.11. Л. 21)

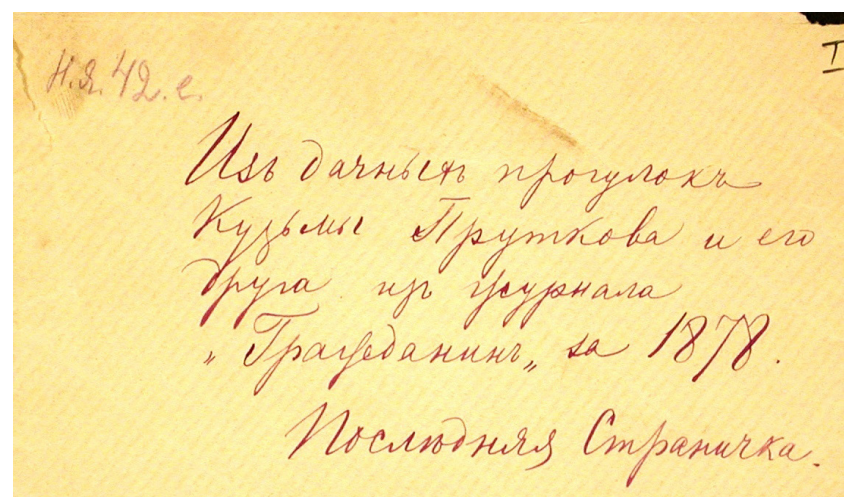

Илл. 5. Надпись на конверте рукой А. Г. Достоевской (ОР РГБ. Ф. 93.І.3.13; наборная рукопись фельетона «Из дачных прогулок Кузьмы Пруткова»)

Таким образом, при определении начальной даты обеих $3 К$ мы можем отталкиваться только от биографических и литературных данных. $3 K_{1}$ Достоевский предположительно вел с января 1860 по октябрь 1862 г. [Заваркина: 76-90]: об этом свидетельствуют записи расчетов, публицистические замыслы и записи припадков. Последние по хронологии записи в $3 K_{1}$ - это разработка «Объявления о подписке на журнал “Время” на 1863 г.» и наброски к «Скверному анекдоту» (первое название «Несчастный случай») 4 . В $3 K_{2}$ на с. 147 (по хронологии и порядку заполнения это одна из первых страниц 
в книжке, см.: Илл. 6) сохранились наброски, которые комментаторами Д30 также отнесены к разработке «Объявления» на 1863 г. (см.: Д30; 20: 368).

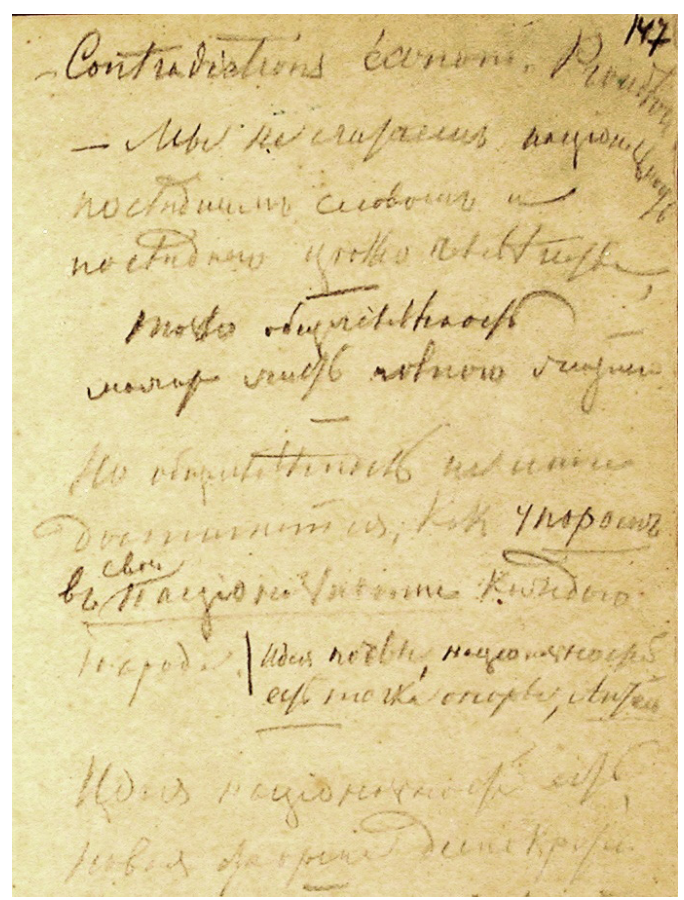

Илл. 6. Фрагмент с. 147

«- Contradictions économ<iques $>$ Proudhon

- Мь не считаемь національность посльднимъ словомь и послььнею ильлью человпчества.

Только общечеловпчность можеть жить полною жизнію.

Но общечеловпчность не иначе достигнется, какъ упоромъ въ \{свои\} національности каждаго народа. \{Идея почвы, національностей есть точка опорь, $\underline{\text { Антей. }}$.

Идея національностей есть новая форма демократіи». 
Вернувшись из-за границы в конце лета 1862 г., Достоевский начинает работать над текстом «Объявления», которое было опубликовано в 9 номере «Времени» за 1862 г. (цензурное разрешение получено 14 сентября). Можно предположить, что Достоевский разрабатывал «Объявление» одновременно в нескольких книжках $\left(3 K_{1}\right.$ и $\left.3 K_{2}\right)$. Параллельная работа в нескольких книжках и тетрадях характерна для творческой манеры писателя: в 1864 г. вместе с $3 K_{2}$ Достоевский делает записи в тетрадях более крупного формата, которые позже получат название «письменные книги» [Розенблюм: 9]. «Третья» $3 К$, хранящаяся в фонде ОР РГБ (93.I.2.8), окажется последней книжкой небольшого формата, в ней собственно литературных записей становится еще меньше, ее Достоевский тоже заводит параллельно с $3 K_{2}$ в 1864 г.

Но тогда верхняя датировка $3 K_{2}$ должна быть отодвинута на август-сентябрь 1862 г. (когда собственно и разрабатывалось «Объявление»), чего сказать с уверенностью нельзя. Во-первых, в $3 K_{1}$ оставалось еще достаточно пустых страниц для продолжения работы над «Объявлением» (пусть и в другой части книжки). По мнению В. Н. Захарова, чистые листы и пропуски появлялись в записных книжках и тетрадях Достоевского не случайно [Захаров, 2018: 92]: возможно, Достоевский предполагал продолжить разработку той или иной идеи позже. Вовторых, наброски на с. 147 отнесены комментаторами Д30 также и к разработке “Ответа редакции “Времени” на нападение “Московских ведомостей”», над которым Достоевский трудился уже в середине 1863 г. (см.: Д30; 20: 368, 316-317).

В исследовательской литературе высказано мнение, что Достоевский в $3 K_{2}$ мог возвращаться к тексту уже опубликованного «Объявления» позже - в 1863 г. (см.: (Д30; 20: 361, 365), [Достоевский. Словарь: 377]). Так, кроме записей на с. 147, к «Объявлению» 1863 г. комментаторами Д30 отнесены и записи на с. 75 3К (см.: Илл. 10): «Достоевский возвращается к мысли, выраженной в объявлении об издании “Времени” на 1863 г.» (Д30; 20: 365): 


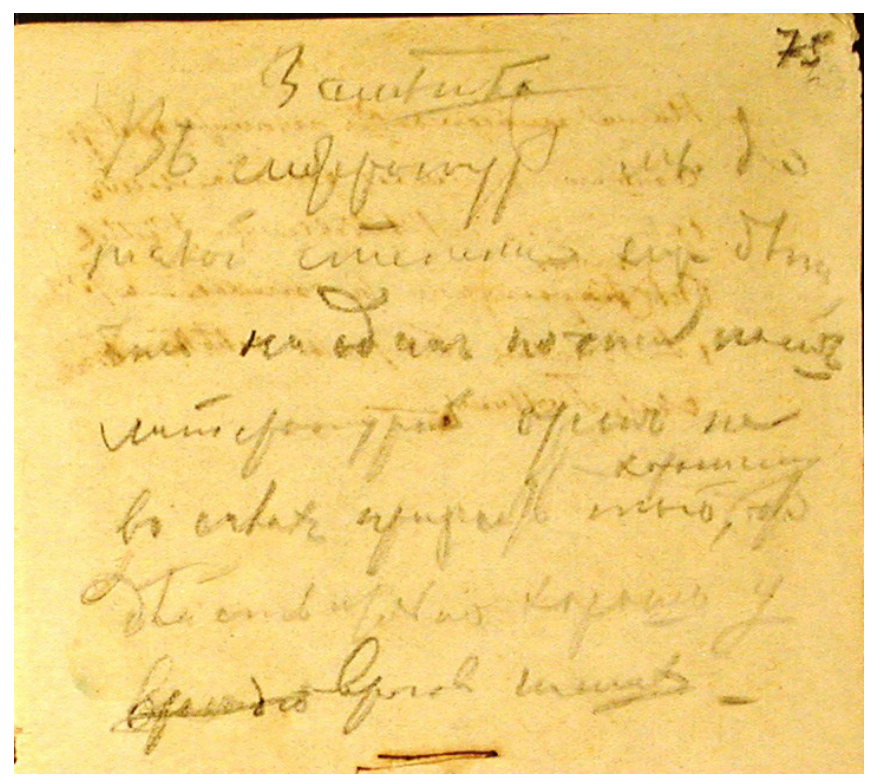

Илл. 7. Фрагмент с. $753 K_{2}$

\section{«замптка}

Въ титератург мы до такой степени еще дтоти, что ни одинг почти нашъ литературный органг не вг силахъ признать того \{хорошаго\}, что дюйствительно хорошо у [враждеб] враговъ нашихъ. 一» $\left(3 K_{2}\right)$. Ср.: «Мы хвалимъ хорошее и во враждебныхъ намъ изданіяхъ и никогда изъ кумовства не похвалили худого у друзей нашихъ. Увы! неужели такую простую вещь приходится въ наше время ставить себъ въ заслугу?» (Ө. Д.; V: 470).

Добавим только, что в $3 K_{2}$ Достоевский мог вернуться к тексту уже опубликованного «Объявления» не только в 1863 г., но и в последние месяцы 1862 г., что не исключает обе датировки: «1862-1864» и «1863-1864». В «Объявлении» на 1863 г. Достоевский полемизировал с отдельными критиками и публицистами разных направлений, в том числе с «теоретиками» «Современника» и «Русского слова», с «доктринерами» «Русского вестника» (см.: Д30; 20: 393-394). С июня 1862 г. журналы «Современник» и «Русское слово» были закрыты по цензурным соображениям на 8 месяцев. По мнению Л. М. Розенблюм, «еще до возобновления “Современника” Достоевский 
предусматривал новый этап борьбы с “обличителями”» [Розенблюм: 38]. Полемика была возобновлена в начале 1863 г., и Достоевский в конце 1862 г. к ней, безусловно, готовился: «Но по-настоящему серьезная, а по тону необыкновенно резкая полемика с программой “Времени”, изложенной в объявлении, развернулась в 1863 г., особенно после заметки Ф. М. Достоевского “Необходимое литературное объяснение по поводу разных хлебных и нехлебных вопросов”», в которой были развиты некоторые идеи «Объявления»на 1863 г. и в целом продолжена программа «Времени» (Д30; 20: 395, 292). Статья вышла в январском номере журнала «Время» за 1863 г., цензурное разрешение было получено уже 11 января, то есть работу над статьей Достоевский начал либо в конце 1862 г., либо в самом начале 1863 г.

Также в последние месяцы 1862 г. и в начале 1863 г. Достоевский работал над «Зимними заметками о летних впечатлениях», которые вышли в февральском и мартовском номерах «Времени» за 1863 г. [Нечаева, 1972: 159], (Д30; 5: 357), (Д35; 5: 416). Однако в $3 K_{2}$ нет набросков этого произведения ${ }^{5}$.

В Д30 при определении начальной даты ведения $3 K_{2}$ (1863 г.) отталкиваются от трех основных пунктов:

1. размышления Достоевского о польском восстании, произошедшем в январе 1863 г. (с. $1513 K_{2}$ );

2. упоминание статьи М. П. Погодина «Петр первый и национальное, органическое развитие», опубликованной в июльском номере «Русского вестника» за 1863 г. (с. 153 $\left.3 K_{2}\right)$;

3. упоминание писателем статьи И. М. Сеченова «Рефлексы головного мозга», напечатанной в №№ 47-48 «Медицинского вестника» 1863 г. (с. $1533 K_{2}$ ).

Все эти записи сделаны на последних страницах, которые по хронологии заполнялись первыми. Бо́льшую часть остальных записей публикаторы Д30 относят к 1864 г. (Д30; 20: 360). Однако полностью исключать последние месяцы 1862 г. мы не можем, учитывая данные, связанные с «Объявлением» на 1863 г. и статьей «Необходимое литературное объяснение по поводу разных хлебных и нехлебных вопросов». 
Для установления хронологических рамок данной $3 К$ важной оказывается первая страница. Так как книжка велась Достоевским в обратном направлении, по хронологии первая страница оказывается одной из последних, именно поэтому в ЛН она публикуется в конце книжки [ЛН, т. 83: 188]. В Д30 страница воспроизведена в 27 томе, среди «Записей личного и издательского характера из записных книжек и рабочих тетрадей 1860-1881 гг.» (Д30; 27: 93).

В примечаниях к публикации $3 K_{2}$ в 20 томе Д30 запись «25 ноября / 63 выпздъ изъ Москвы», которой открывается страница, определена как «датированная» (см.: Д30; 20: 360), что кажется не совсем точным. По нашему мнению, данная страница заполнялась уже после смерти жены и брата, скорее всего, где-то в августе 1864 г. В середине страницы есть другая датированная запись («2 августа. Утро въ Павловски...»), которая подводит «итог» переживаниям Достоевского по поводу смерти самых близких людей (см.: Илл. 8).

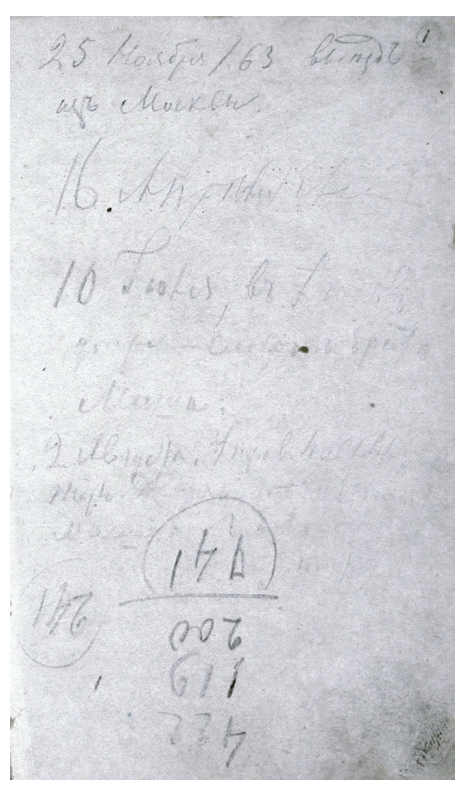

Илл. 8. С. $13 K_{2}$
«25 ноября / 63 вьюздъ изг Москвьь. 16 Априоля (Еһеu)

10 Іюля, въ 7 часовъ утра - смерть брата Мищu.

2 августа. Утро въ Павловскп. Тург<еневъ >. Дворянское гнпздо (начало).

Маша и братъ, будущность, потомь настоящее».

Следует сказать, что в ЛН и Д30 предпоследнюю запись прочитывают по-другому: «2 августа. Утро в Павловске. [Жары. “Дворянское гнездо” (начало)]» [ЛН, т. 83: 188] / «2 августа. Утро в Павловске. Жарко. “Дворянск<ое> гнездо” (начало)» (Д30; 27: 93). Одинаково с Д30 данная запись прочитана также в статье Т. И. Орнатской [Орнатская: 224] и в Летописи [Летопись: 464]. 
Вместо слов «Жары» и «Жарко» мы видим сокращенную фамилию автора «Дворянского гнезда» — «Тург.» (см.: Илл. 9).

Илл. 9. Фрагмент с. $13 K_{2}$

Ср. в ЗК на с. 61 (ОР РГБ. Ф. 93.I.2.6) похожее сокращение («я у Бекетовы<хъ> идукъ Тург<еневу>») (см.: Илл. 10).

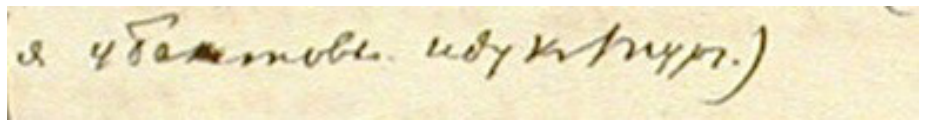

Илл. 10. Фрагмент с. $613 K_{1}$

Вернемся к датам. 25 Ноября 1863 г. Достоевский выехал из Москвы в Петербург, куда он до этого, 11 ноября, из Владимира привез больную жену, М. Д. Достоевскую, опасаясь ухудшения ее здоровья [Летопись: 428, 430]. Достоевский живет на два города (Петербург, Москва), постоянно навещая больную жену. Окончательно возвращается в Москву он только в конце декабря 1863 г. [Летопись: 434] и, совершив только одну поездку в Петербург, с 19 по 27 февраля 1864 г. [Летопись: 439-440], (Д30; 28: 539), до самой смерти Марии Дмитриевны остается при ней. Почему дата «25 Ноября 1863 г.» оказалась важной для Достоевского? С ретроспективной точки зрения это был новый и последний рубеж в их совместной жизни.

Дата «16 Априля (Еheu)» связана уже со смертью Марии Дмитриевны, скончавшейся накануне 15 апреля 1864 г. Латинское «Eheu» («Увы!»), не прочитанное в первой публикации $3 K_{2}$ в ЛН [ЛН, т. 83: 188], по справедливому указанию Т. И. Орнатской, появлялось у Достоевского и ранее, 
например, в «Сибирской тетради», и тоже в связи с первой женой писателя [Орнатская: 223-224].

Дата «10 июля» <1864 г.> - день смерти брата писателя, Михаила Михайловича. Позже, 29 июля, Ф. М. Достоевский писал брату А. М. Достоевскому: «Да мы все никто и не предполагали худого исхода, совершенно никто, даже доктора. <...> В понедельник вечером ему доставили одно известие о запрещении цензурой одной статьи. На другой день он мне сказал, что чувствует себя очень дурно и всю ночь не спал. <...> Позвали Бессера, и тот, отведя меня в сторону, вдруг объявил мне, что нет никакой надежды, потому что в эту ночь произошло излияние желчи в кровь и кровь уже отравлена. Бессер сказал, что брат уже ощущает сонливость, что к вечеру он заснет и уже более не проснется. Так и случилось: он заснул, спал почти покойно и в пятницу 10 числа в семь часов утра скончался, не проснувшись» (Д30; 282:95-96). Федор Михайлович был рядом, и после смерти брата вся тяжесть забот о похоронах и перспективах издания журнала «Эпоха» легла на его плечи ${ }^{6}$.

Итак, первая страница содержит сразу несколько дат (они относятся как к 1863 г., так и к 1864 г.) и становится квинтэссенцией трагических событий в жизни писателя. Так как выстроить записи по датам в хронологическом порядке, как это было с $3 K_{1}$, затруднительно, мы решили сгруппировать записи, относящиеся к 1863 г., и записи, относящиеся к 1864 г. Это поможет в самом общем виде понять последовательность заполнения книжки.

\section{Записи, относящиеся к 1863 г.}

Январь 1863 г. Возможно, одна из самых ранних записей, относящихся к началу 1863 г., - это запись на с. 151 о восстании в Польше, которое произошло в ночь с 10 на 11 января 1863 г. (см.: Илл. 11). Однако набросок был также использован Достоевским в «Ответе редакции “Времени” на нападение “Московских ведомостей” (Д30; 20: 97-101, 361), а значит, может быть датирован и серединой 1863 г. 


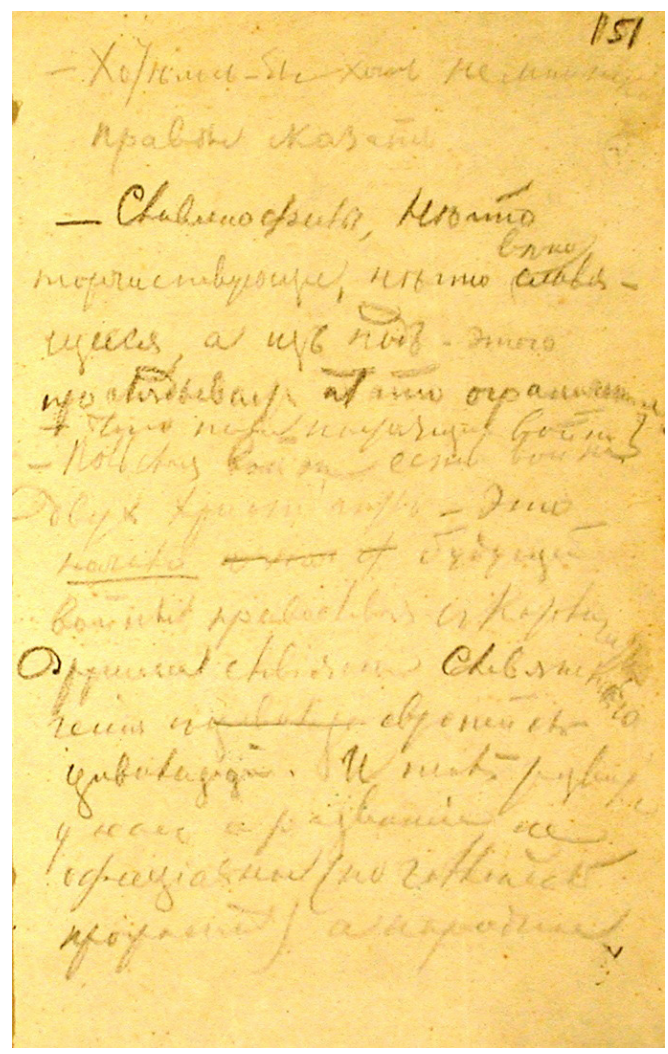

Илл. 11. С. $1513 K_{2}$

В мае 1863 г. журнал «Время» был закрыт по цензурным соображениям из-за выхода в апрельском номере «роковой» статьи Н. Н. Страхова. После запрещения журнала Достоевский, по его словам, не брал пера в руки целый месяц (Д30; $28_{2}$ : 33). Однако это, скорее всего, преувеличение. По воспоминаниям Страхова, Достоевский начал действовать незамедлительно, как только "разнеслись слухи, что журналу угрожаеть опасность»: «...Наконецъ оказалось, что нельзя терять ни одного дня, и тогда Өедоръ Михайловичъ составилъ небольшую замътку объ этомъ дъль, чтобы тотчасъ-же напечатать ее...» [Страхов: 249]. 22 мая в катковской газете «Московские ведомости» вышла заметка Карла Петерсона «По 
поводу статьи “Роковой вопрос" в журнале “Время”». Достоевский отправляет свой «Ответ...» в газету «С.-Петербургские ведомости», но он так и не будет опубликован (Д30; 20: 316).

Тогда в защиту журнала и своей позиции Достоевский будет говорить в открытую, например, в письмах того времени. Так, в письме Тургеневу от 17 июня 1863 г. Достоевский пытается оправдать статью Страхова: «Вы знаете направление нашего журнала: это направление по преимуществу русское и даже антизападное. Ну, стали бы мы стоять за поляков? Несмотря на то нас обвинили в антипатриотических убеждениях, в сочувствии к полякам и запретили журнал за статью в высшей степени, по-нашему, патриотическую» (Д30; 28, 34$)$.

По мнению Г. М. Фридлендера, «статья Страхова не была антиправительственной: исторические взаимоотношения России и Польши освещались в ней с точки зрения славянофильской философии истории <...>. Доказывая превосходство православия над католицизмом, России - над Западом, Страхов давал на этом основании отрицательную характеристику польского национального освободительного движения и высказывался за поддержку политики самодержавия в Польше» [Фридлендер: 103]. Однако статья возбудила широкое недовольство, так как в ней увидели антипатриотический настрой и попытку оправдать польские притязания на русские земли: «Как это бывало у Страхова, он увлекся, говоря о второстепенном, и посвятил основную часть своей статьи разговору о достоинствах польской культуры, а вывод о том, что русская православная цивилизация имеет бесспорное преимущество перед западными началами, последовал лишь в самом ее конце и был сделан не очень внятно» [Фатеев: 185].

Для самого Каткова известие о том, что статью «Роковой вопрос» написал знакомый ему Страхов, стало неприятной неожиданностью. Страхов пытался оправдаться и добился помещения в «Русском вестнике» нового разбора своей статьи (подробнее см.: Д30, 20: 317, 252-255). В работе «По поводу статьи "Роковой вопрос"» Катков предпринял попытку защитить журнал «Время», но в основном его статья была посвящена жесткой критике «роковой» статьи Страхова [Hечаева, 1975: 8]. Позже Страхов вспоминал, что «хотя закрытие 
журнала было катастрофой и для сотрудников и для редакции, но "никто не унывал, и все готовы были смотреть на это происшествие только как на один из крупных случаев обыкновенных литературных превратностей"» [Нечаева, 1972: 308]. На самом деле, закрытие журнала стало катастрофой реальной: «финансовым крахом для издателей журнала "Время", только набравшего солидную подписку, ударом для Достоевского, с которого еще не был снят полицейский надзор, и, конечно, творческой драмой для Страхова, статьи которого за его собственной подписью цензоры долго потом боялись пропускать в печатные издания. А первое время после запрета журнала он вообще был готов к ссылке в Сибирь» [Фатеев: 187].

Итак, несмотря на то, что события, связанные с публикацией статьи Страхова, имели трагические последствия для журнала «Время», в $3 K_{2}$ мы не найдем упоминания о тех роковых днях.

Февраль - май $1863<i>$. Под вопросом остаются записи на c. 24-25, написанные в направлении, обратном основной нумерации. Достоевский делает замечание «объ изобрьт<еніи> оружій» (статья об изобретении нового вида пороха была опубликована в № 40 «Голоса» от 15 февраля 1863 г.). Также он записывает название книги Шедо-Ферроти «Что сделают с Польшей?», опубликованной в 1863 г. Судя по записям, Достоевский хотел развить некоторые идеи в «политическую статью» (см.: Д30; 20: 360-361, 378).

Однако эти записи могут быть отнесены и к 1864 г. Многие идеи из «политической статьи» прорабатывались Достоевским в следующей «третьей» записной книжке (ОР РГБ. Ф. 93.І.2.8), которую писатель вел параллельно с $3 K_{2}$ в 1864 г., а также в рабочей тетради (РГАЛИ. Ф. 212.1.4). Известно, что до этого времени раздел «Политическое обозрение» был поручен А. Е. Разину, который после начавшейся по указу 19 февраля 1864 г. аграрной реформы уехал в Польшу [Нечаева, 1975: 74]. В первом номере «Эпохи» за 1864 г. вышла анонимная статья «Что такое польские восстания», автором которой предположительно являлся А. Е. Разин: «Готовя первую сдвоенную книжку журнала, М. М. Достоевский поместил в ней (без подписи) статью “Что такое польские восстания" (стр. 59). Есть 
все основания предполагать, что она была написана А. Е. Разиным. Лишь закончив ее, он предполагал приступить к работе над внутренним и иностранным обозрением» [Нечаева, 1975: 67]. В. С. Нечаева приводит некоторые доказательства в пользу авторства Разина, включая его письмо, где Разин упоминает какую-то статью, высланную для первого номера «Эпохи» [Нечаева, 1975: 73]. Почему статья все же оказалась без подписи и фамилия Разина в росписи журнала находится под вопросом? Возникли опасения после «роковой» статьи Страхова или авторство было совместным? Например, с Михаилом Михайловичем или Федором Михайловичем, который до этого времени не имел возможности высказаться по польскому вопросу. По словам В. Н. Захарова, «критика, публицистика и полемика были редакционной заботой Федора Михайловича. “Эпоха” началась без него: с ноября 1863 г. по апрель 1864 г. он был в Москве, выхаживая умирающую жену Марию Дмитриевну. В составе первых четырех номеров, которые выпустил в марте - июне 1864 г. Михаил Михайлович, отсутствуют редакционные статьи, почти все тексты подписаны полным авторским именем или узнаваемым псевдонимом <...> В первых номерах “Эпохи” 1864 г. у М. М. Достоевского не было возможности проводить направление в анонимных редакционных статьях (исключение - несколько статей по “польскому вопросу")» [Захаров, 2017: 7, 10]. Была еще одна статья, связанная с польским восстанием, которая должна была появиться в первой книжке «Эпохи», - «Перелом» Н. Н. Страхова. После закрытия журнала Страхов «рвался заявить свой патриотизм и снять с себя обидное обвинение», «он и М. М. Достоевский хотели ее провести как статью редакционную» [Нечаева, 1975: 69]. Однако статья вышла только в 1890 г. в сборнике статей Н. Н. Страхова.

До августовского номера «Эпохи» раздела «Политическое обозрение» не появилось, пока Достоевский не пригласил А. А. Головачева вести не только политическое обозрение, но и внутренние новости. Однако после первого и второго обозрения (опубликованы в августовском и сентябрьском номерах «Эпохи» за 1864 г.), непосредственное участие в которых принял сам Ф. М. Достоевский, пути редактора и сотрудника 
разошлись из-за идейных разногласий: «Вскоре обнаружились новые расхождения взглядов редактора и сотрудника - на свободную торговлю, на внутреннюю политику Англии. Достоевский не разделял экономические пристрастия автора, упрекал его в “западничестве”, позитивизме, либерализме. Головачев оправдывался - и неудачно, лишь усугубляя расхождения» [Захаров, 2016: 8]. См. также: [Нечаева, 1975: 75-79].

Июль 1863 г. Следующие по хронологии записи относятся только к лету 1863 г. Так, к июлю 1863 г. можно отнести записи на с. 8-9 (см.: Илл. 15). Здесь мы видим расчеты, связанные с предстоящей поездкой Достоевского за границу, которая длилась с 4 августа по 21 октября 1863 г. Издатели Летописи считают, что эти записи сделаны до 24 июля 1863 г., как и карандашная запись на с. 50, где Достоевский перед отъездом набрасывает некоторые поручения сестре жены, Варваре Дмитриевне, и своей племяннице Соне по поводу больной Марии Дмитриевны [Летопись: 413] (см.: Илл. 12).

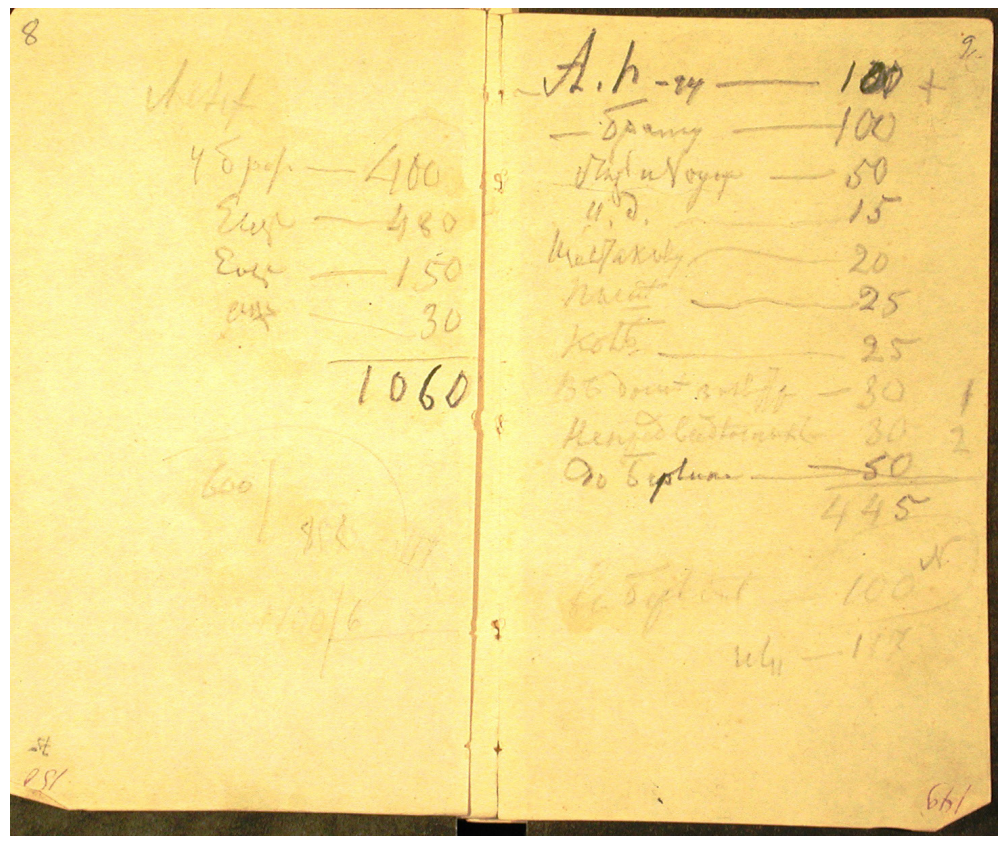

Илл. 12. С. $8-93 K_{2}$ 


\begin{tabular}{|c|c|}
\hline 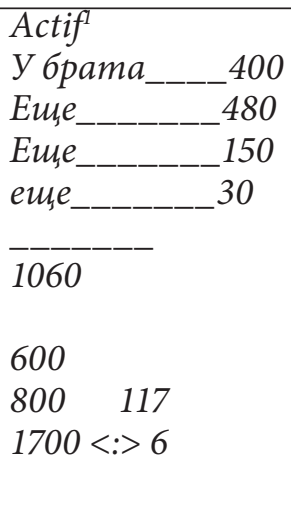 & 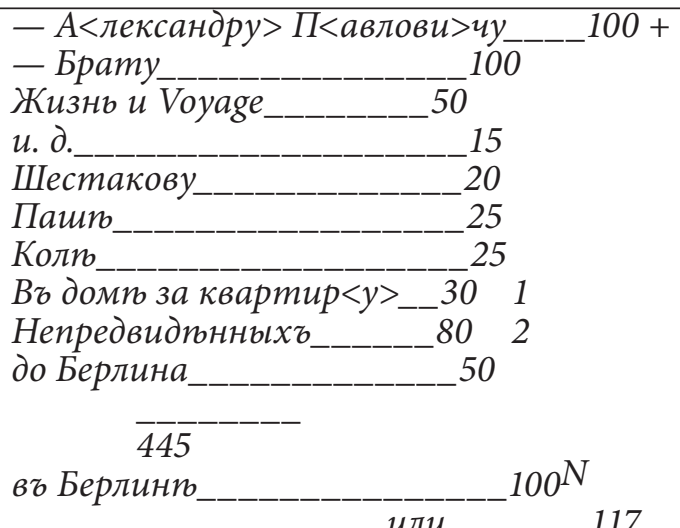 \\
\hline
\end{tabular}

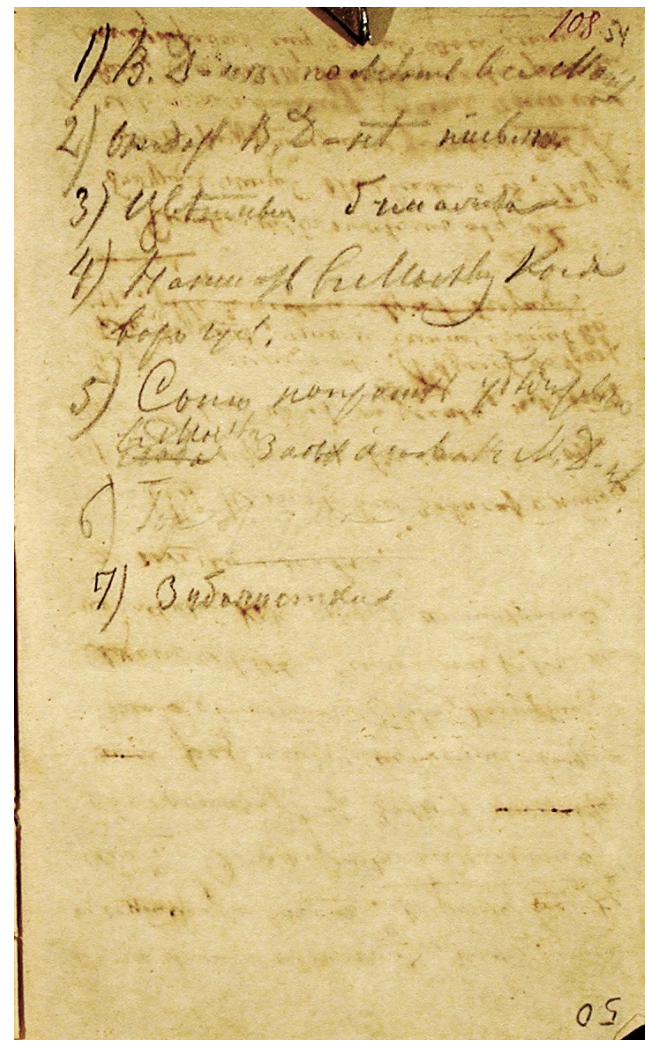

Илл. 13. С. $503 K_{2}$ 
«1) В<арварпь $>$ Д<митріев>ни посылать все Машиь.

2) Отдать В<арварп $>$ Д<митріев>нгь письма.

3) Цвптнныя бумажки.

4) Написать въ Москву когда ворочусь.

5) Соню попросить убюдительно [сюда] $\{в ъ$ Москвю $\}$ запхать $\kappa ъ$ М<арью $>$ Д<митріев>ни.

6) Горе оть ума.

7) Зубочистки».

Записи на с. 50 сделаны наскоро карандашом и небрежным почерком в направлении, противоположном основной нумерации книжки. Такой разброс записей, относящихся буквально к одному месяцу (с. 8-9 и 50), еще раз свидетельствует о хаотичном ведении Достоевским своих записных книжек: он наскоро записывал важные для него мысли на первой попавшейся странице.

На с. $213 K_{2}$ есть датированная запись, относящаяся к 24 июля и прочитанная в исследовательской литературе как «24 Іюля. Eheu». Она находится над набросками с переработкой повести «Двойник», начатой еще в $3 K_{1}$. В Летописи и в «Уточнениях и дополнениях к комментарию Полного собрания сочинений Достоевского. “Сибирская тетрадь” Т. И. Орнатской [Орнатская: 224] ее связывают с Марией Дмитриевной, соотнося записи с этой страницы и со с. 8-9 и 50. 24 июля 1863 г. Достоевский подписывает у маклера Ив. Денисова «обязательство о возвращении Лит. фонду ссуды в 1500 руб.» (Д30; 30 2 : 28-29), [Летопись: 414], выданной ему для лечения от падучей болезни за границей. По мнению Т. И. Орнатской, дата «24 июля» относится к лету 1863 г., когда Достоевский получает ссуду и собирается в заграничное путешествие с А. П. Сусловой, ожидавшей его в Париже: «...новая веха в отношениях с Сусловой заставила Достоевского как бы еще раз вспомнить грустную историю его первой любви» [Орнатская: 224].

Летом 1863 г. Марья Дмитриевна была еще жива, и в таком случае данная помета свидетельствовала бы о лицемерии Достоевского и даже о какой-то жестокости по отношению к больной умирающей жене, о здоровье которой он так беспокоился до отъезда и во время поездки. См., например, письмо к брату, Николаю Михайловичу, от 16 августа 1863 г.: 
«Как-то мне грустно теперь, и тоска. Голова болит притом. Думаю о всех вас; думаю часто и о Марье Дмитриевне. Как бы, как бы хотелось получить об ней добрые известия! Что-то ее здоровье?» (Д30; 28: 38). Да, после смерти Марии Дмитриевны, Достоевский сделает известную запись от 16 апреля об эгоистичной природе человека и невозможности возлюбить другого как самого себя: «Маша лежить на столю...». Но она свидетельствует, скорее, о чувстве вины писателя, пытавшегося, как и герой его будущего романа «Идиот», князь Мышкин, совместить в своем сердце две разные любви к двум разным женщинам. О важности этих набросков для истории создания романа «Идиот» писали многие исследователи (И. А. Кириллова, К. А. Степанян, А. Б. Галкин, С. А. Кибальник и др.).

Однако в Летописи записи на с. 16-19 и далее, на с. 21-22, где идет переработка повести «Двойник», относят также и к лету 1864 г.:

«Июня конеи. Д. возвращается [из Москвы] в Петербург и приступает к переделке “Двойника"» [Летопись: 458].

«Июля 24. Д. продолжает работать над “Двойником" <...> В Записной книжке 1863-1864 гг. под этой датой появляется запись: “Голядкин, продолжение...”" [Летопись: 462].

Таким образом, в Летописи одну и ту же дату («24 июля») и одну и ту же страницу (с. 21) $3 K_{2}$ относят как к 1863, так и к 1864 г.

Надо сказать, что дата «24 июля» вписана теми же чернилами и тем же почерком, что и сами наброски повести, и сделана единовременно с работой над «Двойником»: «Голядки<нъ> продолженіе 24 Іюля. Ehеи» (см.: Илл. 14).

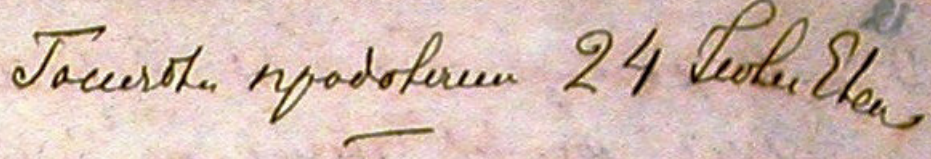

Илл. 14. Фрагмент с. $213 K_{2}$ 
Дата «24 июля» относится, скорее всего, не к 1863 г. (времени отъезда Достоевского за границу), а к 1864 г., когда (именно 24 июля) вдове Э. Ф. Достоевской было разрешено продолжать издавать журнал «Эпоха» под редакцией А. У. Порецкого [Летопись: 462]. Возможно, восклицание «Еheu» (Увы!) относится не к Марии Дмитриевне, а к недавно умершему (10 июля) брату Михаилу. После смерти брата, Достоевский получает разрешение, пусть и под официальным руководством других людей, продолжать издавать любимый журнал. Ведь до этого он издавался под руководством Михаила Михайловича. Грустное «Eheu» (Увы!) - это дань памяти не только родному человеку, но и помощнику в нелегком издательском деле. Позже, 29 июля 1864 г., Достоевский пишет брату Андрею Михайловичу: «Дела по редакции (огромные и сложные дела) - всё это я принимаю на себя <...> Я остаюсь в сущности редактором журнала» (Д30; 28, 96). По мнению А. С. Долинина, несмотря на то, что прошение об утверждении Порецкого было подано вдовой Михаила Михайловича, Эмилией Федоровной, оно принадлежит перу Ф. М. Достоевского [Долинин: 562].

Осень 1863 г. Вернемся ко второй половине 1863 г., когда Михаил Михайлович был жив. На с. 117 3К 2 Достоевский делает карандашные наброски:

Илл. 15. Фрагмент с. $1173 K_{2}$

«Да я жить хочу

1) $\{\text { Виччная }>\}^{8}$ Жизнь есть роскошь

Мальтусъ, Писаревъ

Яблоко нарисованное и яблоко диьиствительное» (см.: Илл. 15).

Перед нами набросок полемики с журналами «Русское слово» и "Современник». В №№ 9, 11-12 «Русского слова» за 1863 г. Д. И. Писарев опубликовал статью «Очерки из истории труда», в которой «разоблачил узкоклассовый характер взглядов Мальтуса» [ЛН, т. 83: 197]. Кроме того, на этой странице Достоевский 
возвращается к полемике с Чернышевским и «Современником» об утилитарном отношении к искусству, начатой им еще в $3 K_{1}$, упоминая известную цитату из магистерской диссертации Чернышевского: «Запись представляет собою, по-видимому, самый ранний набросок для полемики» в $3 K_{2}$ (Д30; 20: 367).

Ко второй половине 1863 г. можно отнести и записи на с. 153, где упоминаются статьи И. М. Сеченова и М. П. Погодина. Несмотря на то, что статья М. П. Погодина «Петр первый и национальное, органическое развитие» была опубликована в июльском номере «Русского вестника» за 1863 г., записи на с. 153 сделаны, скорее всего, не ранее ноября 1863 г., когда в номере 47 (23 ноября) вышла статья И. М. Сеченова «Рефлексы головного мозга». Записи названия статей на этой странице сделаны одним карандашом и одним почерком (см.: Илл. 16).

Больше записей, отно-

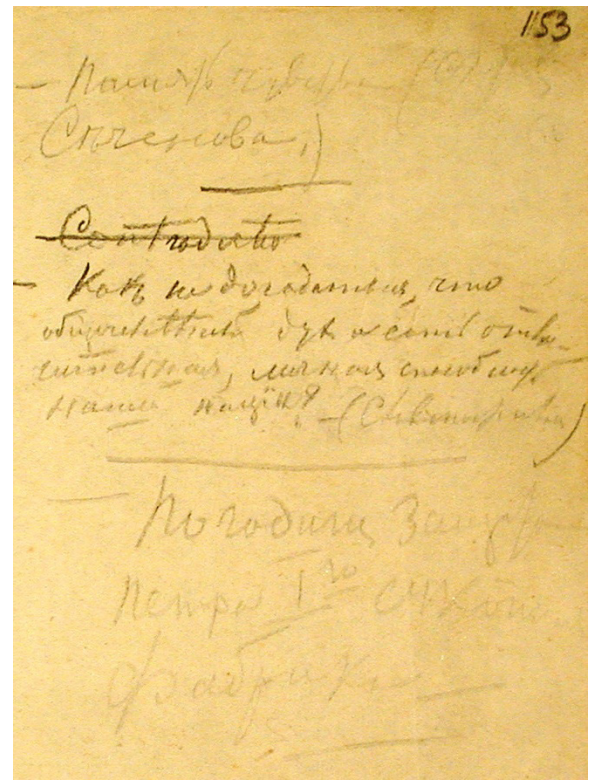
сящихся к 1863 г., обнаружить не удалось. В январе 1864 г. было получено разрешение на издание журнала «Эпоха» под редакцией М. М. Достоевского. Ф. М. Достоевский с осени 1863 до весны 1864 г. был озабочен здоровьем Марии Дмитриевны, да и собственное здоровье подводило [Летопись: 438] — он проводил основное время в Москве, так что Михаил Михайлович издавал журнал один, Федор Михайлович ему лишь помогал.

Илл. 16. С. $1533 K_{2}$

Записи, относящиеся к 1864 г.

Февраль-март 1864 г. Одна из первых возможных записей, сделанных в начале 1864 г., - это запись на с. 65, где Достоевский рассуждает об освобождении польских крестьян, которое 
произошло 19 февраля 1864 г: «Освобождая въ Польши крестьянъ и удюляя имг землю, Россія ужг удюлила Польшп свою мьслль, привила ей свой характерг и эта мьıсль - итьпь съ котор $[y]\{0\}$ 10 теперь Польша съ Россіею Польша связана нераздильно» (см.: Илл. 17). Журнал «Время» был закрыт из-за «польского вопроса», теперь Достоевский вновь осторожно возвращается к польской теме. Возможно, эти рассуждения связаны с записями на c. 24-25 и работой над «Политическим обозрением» и статьей «Что такое польские восстания» (см. выше).

На с. $69,136,138$ видим

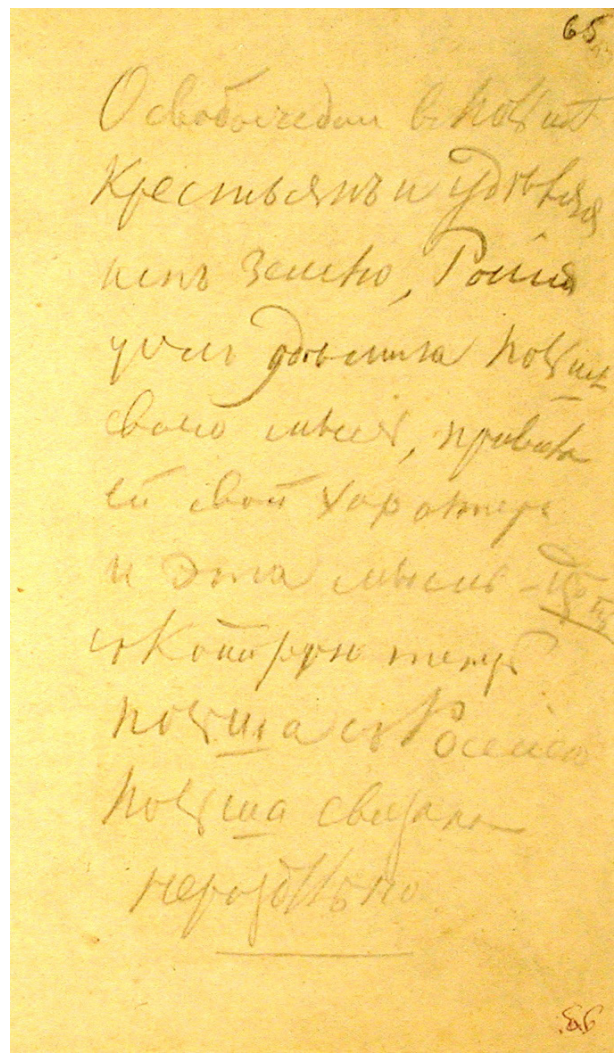

Илл. 17. С. $653 K_{2}$ наброски полемической статьи об историке Н. И. Костомарове. Эта статья должна была развить почвеннические идеи Достоевского и его нового журнала «Эпоха»: «Я ведь не историческую статью хочу писать $<\ldots>$ я знаю что сказать и достаточно даже специалист - не в истории, а в развитии наших идей исторических в литературе, во взглядах наших историков (главнейших) <...> тут все идеи “Эпохи” о “почве” должны быть выражены...» (Д30; 28 $: 74-75)$. На соседней с. 68 Достоевский также рассуждает о почве: «Воротиться къ почви. Никто не можеть быть чимг нибудь или достигнуть чего нибудь не бывъ сначала самимъ собою». Вот как выглядит разворот этого листа (см.: Илл. 18): 


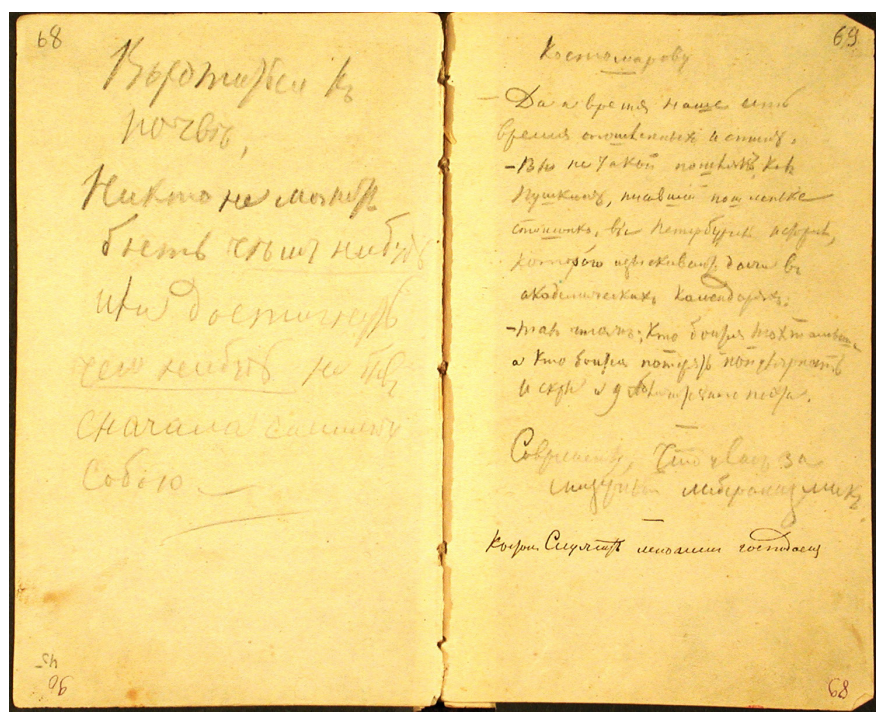

Илл. 18. Разворот листа $3 K_{2}$

Замысел статьи возник у писателя еще в 1860-1862 гг., что нашло отражение в $3 K_{1}$. Комментаторы Д30 начало работы над статьей в $3 K_{2}$ датируют февралем 1864 г. на основании письма Достоевского к брату М. М. Достоевскому от 29 февраля: «С завтрашнего же дня сажусь за статью о Костомарове» (Д30; 28: 66). По мнению В. А. Викторовича, Достоевский планировал написать статью о споре двух историков (Н. И. Костомарова и М. П. Погодина), развернувшемся в 1864 г. Первый опровергал в своих статьях идеалы российской истории (пытался развенчать Дмитрия Донского, Минина и Пожарского, Сусанина). Второй, хоть и выступал против уничижительных статей Костомарова, все же не был близок Достоевскому своим «официозным», «подкупным» патриотизмом [Викторович: 141] ${ }^{9}$. По мнению исследователя, позиция Достоевского была шире и глубже позиций обоих историков и сходилась с пушкинской, например, в понимании личности другого российского деятеля - Петра I: «Вслед за Пушкиным <...> Достоевский хочет понять не только величие, но и конкретно-исторические противоречия Петра как человека и государственного деятеля» [Викторович: 141], то есть в целом увидеть не только отрицательную (как Костомаров) и не 
только положительную (как Погодин) сторону любого российского деятеля. Поэтому запись о Пушкине на с. 76 («- Наши либеральныя тупицы провозглашають Пушкина отсталымь сравнительно съ Рылтевымъ. Рылтевъ быль \{полько К Карамзинб въ стихахъ - и только. А Пушкинъ быль русскій человпкъ и отыскаль Бюлкина. -») В. А. Викторович тоже связывает с замыслом статьи о Костомарове и Погодине [Викторович: 141-142].

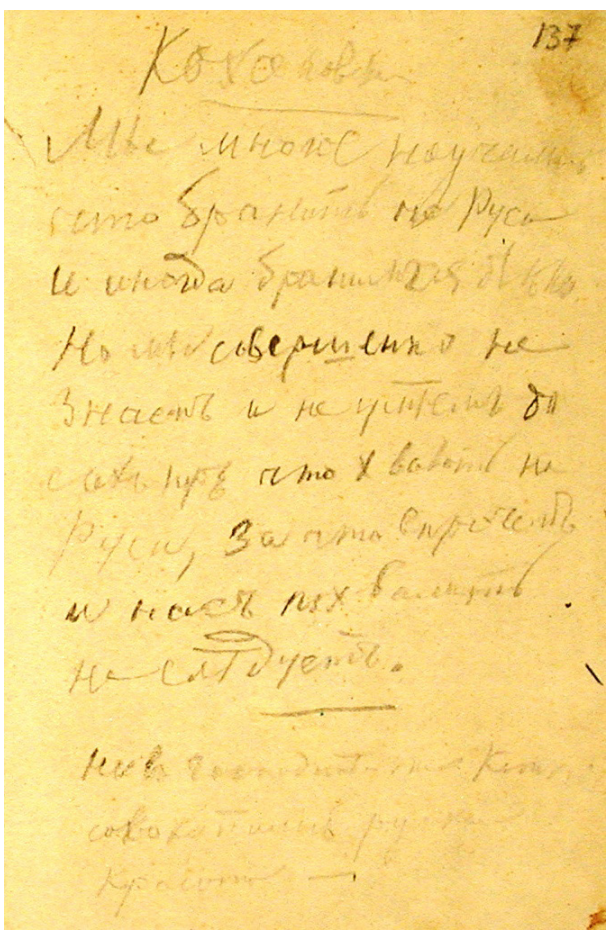

Более того, на с. 137-138 $3 K_{2}$, по мнению Викторовича, Достоевский делает наброски статьи о Дмитрии Донском, образ которого в уничижительном тоне был охарактеризован в статье Костомарова «Куликовская битва» [Викторович: 137-138]. Достоевский пишет: «Мь много научились что бранить на Руси...» (см.: Илл. 19). Эта запись была также предназначена для статьи, посвященной Н. С. Соханской (Кохановской), по поводу ее повести «Рой Федосей Саввич на спокое», опубликованной в «Дне» 1 февраля 1864 г. (см. письмо к брату М. М.Дос-

Илл. 19. С. $1373 \kappa_{2}$

тоевскому от 5 марта 1864 г. - Д30; 282: 68-69). Позже запись на с. 137, по мнению редакторов ЛН, была развита Достоевским в «Объявлении» об издании журнала «Эпоха» на 1865 г. (опубликовано: «Эпоха». 1864. № 8) [ЛН, т. 83: 190].

Запись на с. 138, по мнению В. А. Викторовича, также направлена против «“подкупного” патриотизма антикостомаровских статей» М. П. Погодина [Викторович: 141]: «- Кто слишкомъ крпоко стоить за насильственную иъллость Россіи, во что-бы то ни стало, тоть не вторить въ силу русскаго 
духа, не понимаеть его, а если понимаеть, то явно ему зла желаетъ» (см.: Илл. 20).

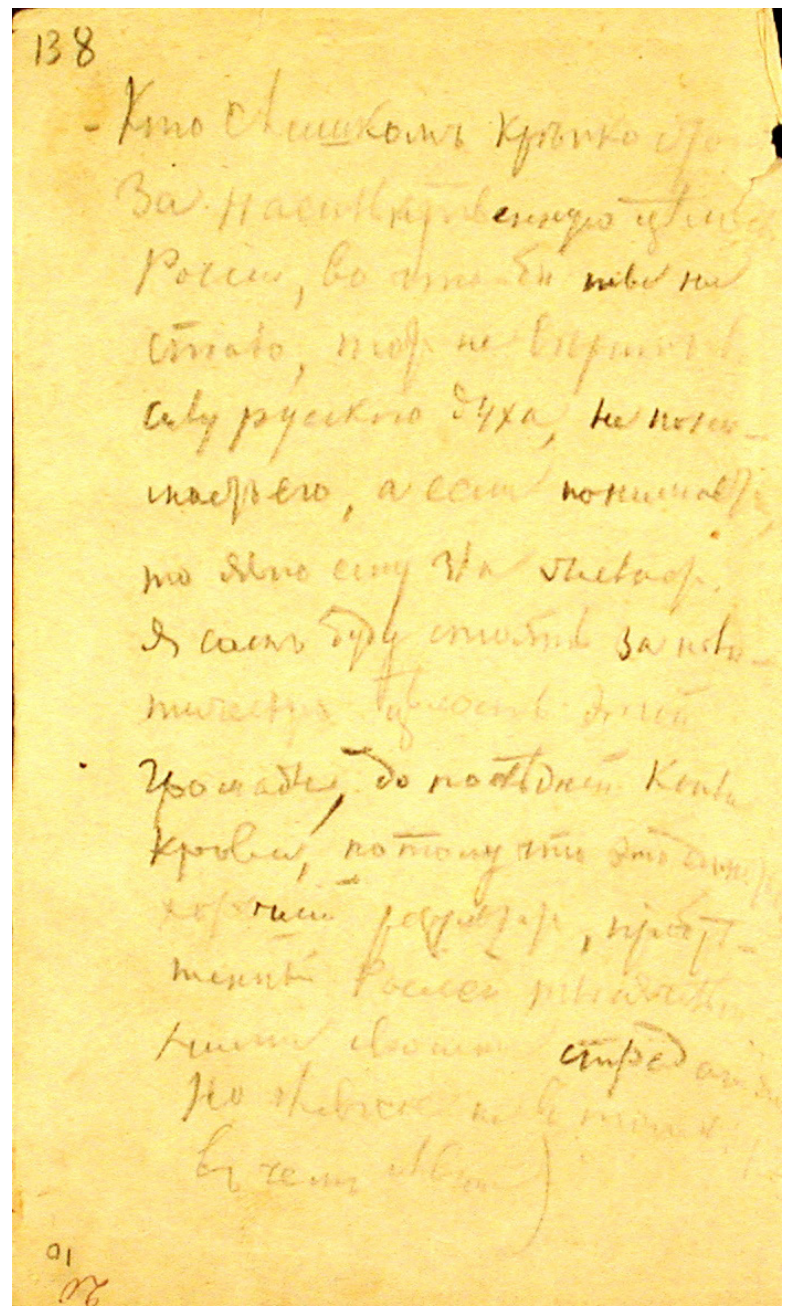

Илл. 20. С. $1383 K_{2}$

По мнению редакторов Д30, эта запись, вероятно, как и последующие, сделана при обдумывании Достоевским «Объявления» об издании журнала «Эпоха» на 1864 г. (Д30; 20: 368). В январе 1864 г. Ф. М. Достоевский находился в Москве, и «Объявление» было составлено без его участия, однако 
М. М. Достоевский руководствовался советами, которые Федор Михайлович изложил в письме от 19 ноября 1863 г. (см. подробнее: Д30; 20: 397; 28: 56-57). Таким образом, хотя само «Объявление» Михаил Михайлович написал после 27 января 1864 г., то есть после получения окончательного решения об издании журнала «Эпоха» [Нечаева, 1975: 12-13], идеи будущего «Объявления» разрабатывались Ф. М. Достоевским задолго до этого - осенью 1863 г.

Задуманной статьи о Костомарове и Погодине Достоевский не написал, но поручил ее Аверкиеву, выразив желание, чтобы он писал о Костомарове, а не о споре его с Погодиным (Д30; 20: 364). Статья Аверкиева «Г. Костомаров разбивает народные кумиры» вышла в третьем номере «Эпохи» за 1864 г. (цензурное разрешение было получено 23 апреля 1864 г.). Полемика продолжилась и в следующем номере.

На с. 75, рядом с заметкой о Пушкине, есть запись, которую предположительно относят к наброску статьи о теоретиках «Современника» (см.: [ЛН, т. 83: 190], (Д30; 20: 365)). О замысле статьи Достоевский упоминал в письме к брату Михаилу от 29 февраля 1864 г.: «Выдумал еще великолепную статью на теоретизм и фантастизм теоретиков (“Современника”) <...> Будет не полемика, а дело. С завтрашнего же дня сажусь за статью о Костомарове» (Д30; 282: 66). Как видим, разработка обеих статей происходила примерно в одно время - весной 1864 г.

На с. $1543 K_{2}$ находим отклик Достоевского на строки стихотворения И. И. Гольц-Миллера (без названия), напечатанного в февральском номере «Современника» за 1864. В 4 книге «Эпохи» за 1864 г. вышла статья Н. Н. Страхова «Заметки летописца» с пародией на это стихотворение (С. 368). Стихотворение высмеивается самим Достоевским и позже: в одном из черновых вариантов «Крокодила» [ЛН, т. 83: 189].

Anрель 1864 2. Следующие по хронологии записи находятся на с. 41-49, 51-55 и начинаются со слов: «16 Апрпоя, Маша лежить на столгь. Увижусь ли съ Машей?». По мнению Л. М. Розенблюм, «личность Достоевского - человека и мыслителя с большой силой и полнотой предстает перед нами на тех страницах записной книжки, которые посвящены смерти М. Д. Исаевой» [Розенблюм: 15]. Как известно, эти мысли, записанные 
Достоевским после смерти первой жены Марии Дмитриевны 15 апреля 1864 г., были развиты им в конспект статьи «Социализм и христианство» осенью 1864 г. в другой записной тетради (РГАЛИ. Ф. 212.1.4) [Розенблюм: 40]. Летопись датирует эти записи второй половиной сентября [Летопись: 478]. Редакторы Д30 относят сюда же записи на с. 23, где Достоевский «продолжает спор с революционными и атеистическими идеалами “Современника”. Подробнее позитивные идеи свои он развил в материалах к неосуществленной статье "Социализм и христианство”» (Д30; 20: 363). По мнению С. А. Кибальника, знаменитая запись от 16 апреля 1864 г. также представляет собой ключ к другим художественным произведениям Достоевского («Запискам из подполья» и роману «Идиот»), а в $3 K_{2}$ и в записной тетради 1864-1865 гг. высказывается важная для понимания романа «Идиот» и, может быть, для всего творчества писателя христианская идея о том, что способность принести себя в жертву ради других - это признак подлинной высокоразвитой личности [Кибальник: 42-43].

Май - август 1864 г. Далее по хронологии идут записи, связанные в основном с развертыванием нового журнала (расчеты, списки авторов и их статей, гонорарные списки). На c. 14-15 видим названия статей майского и июньского номеров «Эпохи» за 1864 г. Далее со с. 16 начинается переделка повести «Двойник», начатая в конце июня 1864 г. [Летопись: 458]. На с. 63 Достоевский набрасывает план будущего собрания сочинений (Д30; 27: 93). Летопись датирует его началом июля 1864 г. [Летопись: 459]. Это собрание сочинений было выпущено Ф. Т. Стелловским в 1865-1870-х гг. На с. 141 видим датированную запись (24 июля 64 года): «Мои счеты съ журналомъ». На с. 32-35 находим роспись июньской, июльской и августовской книжек «Эпохи» за 1864 г. На с. 86 опять видим роспись июльской книжки и планы августовского номера «Эпохи» за 1864 г. И снова разброс записей.

С. 128 содержит дату «10 Августа» и запись: «Дорога 75». После 10 августа 1864 г. Достоевский уезжает в Москву, где проводит несколько дней [Летопись: 464]. Через год в письме к А. Е. Врангелю от 31 марта - 14 апреля Достоевский вспоминает: «Поехал в Москву, выпросил у старой и богатой моей 
тетки 10 000, которые она назначала на мою долю в своем завещании, и, воротившись в Петербург, стал додавать журнал» (Д30; 282: 118). На с. 131 появляется запись: «Расходъ въ Москвю. 11 августа». На с. 26. под датой «16 августа» осталась запись: «Если теперь заводить - надо денегъ...». Видимо, Достоевский вернулся из Москвы с деньгами для продолжения журнала.

На этой же странице, выше, теми же чернилами и почерком в заголовок страницы вынесена запись: «Расчеть Гаврилова». Михаил Гаврилович Гаврилов - служащий типографии К.-Э. Праца, где издавались журналы братьев Достоевских «Время» и «Эпоха». Он неоднократно ссужал деньгами Ф. М. Достоевского. В письме к Э. Ф. Достоевской от 9 (21) августа 1868 г. писатель так характеризует Гаврилова: «...я с Мих<аилом> Гав $<$ риловичем $>$ Гавриловым делывал уже неоднократно, удачно и счастливо, большие и тысячные дела <...> он знает меня за человека верного и состоятельного (и сверх того, не перестающего заниматься литературой, а Гаврилов занимается изданиями)...» (Д30; 282: 311). Ранее в письме А. Н. Майкову от 22 июня (4 июля) 1868 г. Достоевский давал более жесткую характеристику своему кредитору: «...Гаврилов - человек горячий (и трусливый вместе) и предприимчивый» (Д30; 282: 305).

На с. 87 находим дату «19 Августа», а на с. 91 указан месяц «Августъ». И там и там речь идет о составе очередного номера «Эпохи». Начиная с седьмой книжки, журнал «Эпоха» печатался в типографии Н. Тиблена [ЛН, т. 83: 197]. Видимо, после смерти Михаила Михайловича и после того, как Достоевский стал издавать журнал «Эпоха» в другой типографии, появилась необходимость рассчитаться и с Гавриловым. Но сделать это именно тогда Достоевский не смог и выдал Гаврилову вексель на 1000 руб. Точную сумму долга (1000 руб.) Достоевский называет в письме к В. И. Губину от 8 (20) мая 1871 г. (Д30; 29, 210-211). В мае 1865 г., после закрытия журнала «Эпоха», Гаврилов предъявит вексель Достоевскому. Сохранилось одно письмо М. Г. Гаврилова. В нем он требует, чтобы Достоевский уплатил до 1 июня 1865 г. 1000 руб. по векселю, в противном случае Гаврилов угрожает предъявить вексель, что и было сделано летом 1865 г. (см.: Д30; 7: 410). В 1865 г. Достоевский знакомится с издателем Ф. Т. Стелловским, который выкупает 
векселя Достоевского (в том числе по долгам брата), среди которых был и вексель Гаврилова, и принуждает писателя за 3000 руб. заключить известный кабальный договор. В письме В. И. Губину Достоевский жалуется: «И вот, хоть и не могу доказать юридически, но знаю наверно, что вся эта проделка внезапного требования денег (особенно по векселям Демиса) возбуждена была Стелловским: он и Гаврилова тоже натравил тогда» (Д30; 29, :211). Достоевский расплатился по векселю Гаврилова только в июле 1865 г.: «Я расплатился с Демисом, с Гавриловым и с другими и с оставшимися 35 полуимпериалами поехал за границу» (Д30; 29: 211).

В записи на с. 83 «Сальясъ, палку...», по мнению Л. Р. Ланского и С. С. Борщевского, содержится отклик Ф. М. Достоевского на «Путевые очерки Испании» графа Евгения Андреевича Салиаса де Турнемир, которые были опубликованы в «Голосе» (1864. № 227. 18 августа) [ЛН, т. 83: 192]. Также на с. 83 находим отклик на анонимную рецензию «Новый роман автора "Проклятого”». Рецензия, написанная А. Н. Пыпиным и посвященная книге аббата*** «La Réligieuse» («Монахиня»), была опубликована в 6 номере «Современника» за 1864 г. [ЛН, т. 83, 192], (Д30; 20, 362). Это рецензия еще раз упоминается на с. $63 K_{2}$.

В течение 1864 2. На с. 111 Достоевский набрасывает план романа «Пьяненькие», замысел которого относят к 1864 г. (см.: (Д30; 7: 309), [Летопись: 498]).

Итак, исходя из хронологической росписи $3 K_{2}$ однозначно следует отказаться от датировки «1861-1864 гг.» (Д30; 7: 309), [Летопись: 498]. Предложенный Г. М. Фридлендером период заполнения книжки (1862-1864) нуждается в дополнительном обосновании. Не исключается более точная датировка: «последние месяцы 1862 - вторая половина 1864 г.». Достоверно установлено активное заполнение книжки в 1863-1864 гг.

\section{Примечания}

Исследование выполнено при финансовой поддержке РФФИ в рамках научного проекта № 18-012-90028 Достоевский («Рукописное наследие Ф. М. Достоевского: систематизация, исследование, описание»).

Достоевский Ф. М. Полн. собр. соч.: в 30 т. Л., 1972-1990. Далее: Д30, с указанием в тексте в круглых скобках арабскими цифрами тома, нижним индексом - полутома, через двоеточие - страницы. 
2 Достоевский Ф. М. Полн. собр. соч.: канонические тексты / под ред. проф. В. Н. Захарова. Петрозаводск: Изд-во ПетрГУ, 1995-2015-. Далее: Ө. Д., - с указанием в тексте в круглых скобках римскими цифрами тома, через двоеточие арабскими - страницы.

3 Достоевский Ф. М. Полн. собр. соч. и писем: в 35 т. СПб.: Наука, 2013-2019-. Далее: Д35, - с указанием в тексте в круглых скобках арабскими цифрами тома, через двоеточие - страницы.

4 См.: [Заваркина: 72-74, 89].

5 Возможно, существовала еще одна книжка или тетрадь, которую Достоевский вел в этот период. Известно, что осенью 1863 г. в Москве Достоевский потерял сак с документами и вещами (см. письмо к В. Д. Констант от 10 ноября 1863 г. - Д30; 28: 55), среди которых вполне могла быть еще одна записная книжка или тетрадь.

6 Подробнее см.: [Захаров, Захарова: 38-39].

7 наличность, капитал (фр.)

8 В ЛН и Д30 прочитано: «Да но» [ЛН, т. 83: 183], (Д30; 20: 177).

9 В. А. Викторович замечает, что Достоевскому, безусловно, была известна позиция Н. В. Гоголя, близко знавшего М. П. Погодина: «Заговорит ли он о патриотизме, он заговорит о нем так, что патриотизм его кажется подкупной...» [Викторович: 140-141].

\section{Список литературы}

1. Викторович В. А. О двух историко-публицистических замыслах Достоевского // Достоевский. Материалы и исследования. - Л.: Наука, 1985. - Вып. 6. - С. 137-153.

2. Галкин А. Б. Образ Христа и концепция человека в романе Ф. М. Достоевского «Идиот» // Роман Ф. М. Достоевского «Идиот»: современное состояние изучения. - М.: Наследие, 2001. - С. 319-336.

3. Долинин А. С. К цензурной истории первых двух журналов Достоевского // Ф. М. Достоевский. Статьи и материалы / под ред. А. С. Долинина. - Л. ; М.: Мысль, 1924. - Сб. 2. - С. 559-577.

4. Достоевский Ф. М. Полн. собр. соч.: в 30 т. - Л.: Наука, 1972-1990. Т. 5, 7, 20, 27, 282, 291, 302.

5. Достоевский Ф. М. Полн. собр. соч.: канонические тексты / под ред. проф. В. Н. Захарова. - Т. V, VI. - Петрозаводск: Изд-во ПетрГУ, 2004, 2005. (Изд-е продолжается).

6. Достоевский Ф. М. Полн. собр. соч. и писем: в 35 т. - Т. 1, 5. - СПб.: Наука, 2013, 2016. (Изд-е продолжается).

7. Достоевский: сочинения, письма, документы: словарь-справочник / сост. и науч. ред. Г. К. Щенников, Б. Н. Тихомиров. - СПб.: Пушкинский Дом, 2008. - 470 с.

8. Заваркина М. В. Проблемы хронологической атрибуции «первой» записной книжки Ф. М. Достоевского // Неизвестный Достоевский. — 2018. — № 4. - С. 70-93 [Электронный ресурс]. — URL: http:// 
unknown-dostoevsky.ru/files/redaktor_pdf/1545741405.pdf (01.05.2019). DOI: 10.15393/j10.art.2018.3789

9. Захаров В. Н. Идея Достоевского: Усиленное познание России как задача образования // Неизвестный Достоевский. - 2016. - № 3. - С. 3-13 [Электронный ресурс]. - URL: http://unknown-dostoevsky.ru/files/ redaktor_pdf/1477920447.pdf (01.05.2019). DOI: 10.15393/j10.art.2016.2781

10. Захаров В. Н. О статусе редакционных статей в изданиях Достоевского // Неизвестный Достоевский. - 2017. — № 1. - С. 3-17 [Электронный реcypc]. — URL: http://unknown-dostoevsky.ru/files/redaktor_pdf/1493122152. pdf (01.05.2019). DOI: 10.15393/j10.art.2017.3083

11. Захаров В. Н. Поэтика и жанр маргиналий в записных книжках и рабочих тетрадях Достоевского // Проблемы исторической поэтики. 2018. - T. 16. - № 3. - С. 85-100 [Электронный ресурс]. - URL: http://poetica.pro/files/redaktor_pdf/1538994799.pdf (01.05.2019). DOI: 10.15393/j9.art.2018.5461

12. Захаров В. Н., Захарова О. В. Кто автор некрологов по случаю смерти Михаила Михайловича Достоевского? // Неизвестный Достоевский. 2014. - № 1-2. - C. 35-49 [Электронный ресурс]. - URL: http:// unknown-dostoevsky.ru/files/redaktor_pdf/1436966947.pdf (01.05.2019). DOI: $10.15393 / \mathrm{j} 10$. art.2014.3

13. Кибальник С. А. Записные книжки как источник для комментария и интерпретации литературного произведения // Русская литература. 2017. - № 4. - С. 40-51.

14. Кириллова И. А. «Маша лежит на столе...» - утопические и христианские мотивы (к обозначению темы) // Достоевский и мировая культура. Альманах № 9. - М.: Классика плюс, 1997. - С. 22-27.

15. Летопись жизни и творчества Ф. М. Достоевского. 1821-1881: в 3 т. СПб.: Академический проект, 1993. - Т. 1: 1821-1864. - 544 с.

16. Неизданный Достоевский. Записные книжки и тетради 1860-1881 гг. М.: Наука, 1971. - 727 с. (Литературное наследство; т. 83)

17. Нечаева В. С. Журнал М. М. и Ф. М. Достоевских «Время» (1861-1863). М.: Наука, 1972. - 317 с.

18. Нечаева В. С. Журнал М. М. и Ф. М. Достоевских «Эпоха» (1864-1865). М.: Наука, 1975. - 303 с.

19. [Нечаева В. С.] Описание рукописей Ф. М. Достоевского / под ред. В. С. Нечаевой. - М.: Изд-во АН СССР, 1957. - 589 с.

20. Орнатская Т. И. Уточнения и дополнения к комментарию Полного собрания сочинений Достоевского. «Сибирская тетрадь» // Достоевский. Материалы и исследования. - Л.: Наука, 1983. - Вып. 5. - С. 222-225.

21. Розенблюм Л. М. Творческие дневники Достоевского // Неизданный Достоевский. Записные книжки и тетради 1860-1881 гг. - М.: Наука, 1971. - С. 9-92. (Литературное наследство; т. 83)

22. Степанян К. Евангелие от Иоанна и роман «Идиот» // Достоевский и мировая культура. Альманах № 14. - М.: С. Т. Корнеев, 2001. - С. 96-111.

23. Страхов Н. Н. Воспоминания о Федоре Михайловиче Достоевском // 
Биография, письма и заметки из записной книжки Ф. М. Достоевского.- СПб.: Типография А. С. Суворина, 1883. - С. 179-329.

24. Фатеев В. А. М. Н. Катков и Н. Н. Страхов. История отношений двух непохожих мыслителей // Русско-Византийский вестник. - 2019. № 1 (2). - C. 177-203 [Электронный ресурc]. — URL: https://readera. ru/140240260 (01.05.2019). DOI: 10.24411/2588-0276-2019-10012

25. Фридлендер Г. М. Новые материалы из рукописного наследия художника и публициста // Неизданный Достоевский. Записные книжки и тетради 1860-1881 гг. - М.: Наука, 1971. - С. 93-122. (Литературное наследство; т. 83)

Marina V. Zavarkina

(Petrozavodsk, Russian Federation) dostoyevsky@mail.ru

\section{The Problems of the Chronological Attribution of "the Second" Notebook of F. M. Dostoevsky}

Acknowledgements. The reported study was funded by RFBR, project number 18-012-90028 Dostoevsky.

Abstract. The article envisages the problems of the chronological attribution of F. M. Dostoevsky's "second" notebook kept in the Manuscripts Department of the Russian State Library (Fund 93.I.2.7). All the dating information related both to the notebook in whole and to its particular records, is specified. Since the book was filled up in different directions, sometimes chaotically, it is difficult to establish the exact chronological order of records. The article makes a conclusion that the dating of "1861-1864" specified in some publications should be definitely revised. A possibility of keeping a notebook in the last months of 1862 is envisaged, however, the period of "1862-1864" proposed by G. M. Fridlender needs further justification. To understand the sequence of filling up the book, the article grouped and analyzed records relating to 1863 and 1864: it was at that time when Dostoevsky turned to the notebook the most frequently. A lot of questions touched upon in the article are of a polemical character and need further studying.

Keywords: F. M. Dostoevsky, manuscripts, notebooks and workbooks, textual study, attribution, chronology

About the author: Zavarkina Marina V. - PhD of Philology, Teacher of Russian Language and Literature, First Private School (ul. Murmanskaya 28, Petrozavodsk, Republic of Karelia, 185 001, Russian Federation)

Received: May 1, 2019

Date of publication: June 30, 2019

For citation: Zavarkina M. V. The Problems of the Chronological Attribution of "the Second" Notebook of F. M. Dostoevsky. In: Neizvestnyy Dostoevskiy [The Unknown Dostoevsky], 2019, no. 2, pp. 5-39. DOI: 10.15393/j10.art.2019.4081 (In Russ.) 


\section{References}

1. Viktorovich V. A. About Two Historical and Journalistic Ideas of Dostoevsky. In: Dostoevskiy. Materialy i issledovaniya [Dostoevsky. Materials and Researches]. Leningrad, Nauka Publ., 1985, vol. 6, pp. 137-153. (In Russ.)

2. Galkin A. B. The Image of Christ and the Concept of Man in the Novel by F. M. Dostoevsky "Idiot". In: Roman F. M. Dostoevskogo «Idiot»: sovremennoe sostoyanie izucheniya [The Novel by Dostoevsky "The Idiot": the Current State of Studying]. Moscow, Nasledie Publ., 2001, pp. 319-336. (In Russ.)

3. Dolinin A. S. On the Censorship History of the First Two Journals of Dostoevsky. In: F. M. Dostoevskiy. Stat'i i materialy [F. M. Dostoevsky. Articles and Materials]. Leningrad, Moscow, Mysl’ Publ., 1924, vol. 2, pp. 559-577. (In Russ.)

4. Dostoevskiy F. M. Polnoe sobranie sochineniy: $v 30$ tomakh [The Complete Works: in 30 Vols]. Leningrad, Nauka Publ., 1972-1990, vol. 7, 20, 27, 28 (book 2), 30 (book 2). (In Russ.)

5. Dostoevskiy F. M. Polnoe sobranie sochineniy: kanonicheskie teksty [The Complete Works: Canonical Texts]. Petrozavodsk, Publishing House of PetrSU Publ., 2004, 2005, vol. 5, 6. (In Russ.)

6. Dostoevskiy F. M. Polnoe sobranie sochineniy i pisem: $v 35$ tomakh [The Complete Works and Letters: in 35 Vols]. St. Petersburg, Nauka Publ., 2013, 2016 (continued), vol. 1, 5. (In Russ.)

7. Dostoevskiy: sochineniya, pis'ma, dokumenty: slovar'-spravochnik [Dostoevsky: Works, Letters and Documents: Dictionary and Reference Book]. St. Petersburg, Pushkinskiy Dom Publ., 2008. 470 p. (In Russ.)

8. Zavarkina M. V. The Problems of the Chronological Attribution of "the First" Notebook of F. M. Dostoevsky. In: Neizvestnyy Dostoevskiy [The Unknown Dostoevsky], 2018, no. 4, pp. 70-93. Available at: http://unknowndostoevsky.ru/files/redaktor_pdf/1545741405.pdf (accessed on May 1, 2019). DOI: 10.15393/j10.art.2018.3789 (In Russ.)

9. Zakharov V. N. Dostoevsky's Idea: Deeper Understanding of Russia as an Educational Challenge Learning. In: Neizvestnyy Dostoevskiy [The Unknown Dostoevsky], 2016, no. 3, pp. 3-13. Available at: http://unknown-dostoevsky. ru/files/redaktor_pdf/1477920447.pdf (accessed on May 1, 2019). DOI: 10.15393/j10.art.2016.2781 (In Russ.)

10. Zakharov V. N. On the Status of Editorials in Dostoevsky's Periodicals. In: Neizvestnyy Dostoevskiy [The Unknown Dostoevsky], 2017, no. 1, pp. 3-17. Available at: http://unknown-dostoevsky.ru/files/redaktor_pdf/1493122152. pdf (accessed on May 1, 2019). DOI: 10.15393/j10.art.2017.3083 (In Russ.)

11. Zakharov V. N. The Poetics and Genre of Marginalia in Fedor Dostoevsky's Notebooks and Workbooks. In: Problemy istoricheskoj poetiki [The Problems of Historical Poetics], 2018, vol. 16, no. 3, pp. 85-100. Available at: http:// poetica.pro/files/redaktor_pdf/1538994799.pdf (accessed on May 1, 2019). DOI: 10.15393/j9.art.2018.5461 (In Russ.)

12.Zakharov V. N., Zakharova O. V. Who Is the Author of Obituary Notices of Mikhail Dostoevsky's Death? In: Neizvestnyy Dostoevskiy [The Unknown Dostoevsky], 2014, no. 1-2, pp. 35-49. Available at: http://unknown-dostoevsky. 
ru/files/redaktor_pdf/1436966947.pdf (accessed on May 1, 2019). DOI: 10.15393/j10.art.2014.3 (In Russ.)

13. Kibalnik S. A. Notebooks as a Source for Commentaries and Interpretation of a Literary Work. In: Russkaya literatura [Russian Literature], 2017, no. 4, pp. 40-51. (In Russ).

14. Kirillova I. A. "Masha Lies on the Table..." - Utopian and Christian Motifs (On the Designation of Themes). In: Dostoevskiy i mirovaya kul'tura. Al'manakh № 9 [Dostoevsky and World Culture. Almanac No. 9]. Moscow, Klassika Plus Publ., 1997, pp. 22-27. (In Russ.)

15. Letopis'zhizni i tvorchestva F. M. Dostoevskogo. 1821-1881: v 3 tomakh [The Chronicle of Dostoevsky's Life and Works. 1821-1881: in 3 Vols]. St. Petersburg, Akademicheskiy proekt Publ., 1993, vol. 1. 544 p. (In Russ.)

16. Neizdannyy Dostoevskiy: Zapisnye knizhki i tetradi 1860-1881 godov [The Unpublished Dostoevsky: Notebooks and Workbooks of 1860-1881]. Moscow, Nauka Publ., 1971. 727 p. (Ser. "Literary Heritage”; vol. 83). (In Russ.)

17. Nechaeva V. S. Zhurnal M. M. i F. M. Dostoevskikh «Vremya» (1861-1863) [The Journal of Mikhail and Fedor Dostoevsky "Vremya" (1861-1863)]. Moscow, Nauka Publ., 1972. 317 p. (In Russ.)

18. Nechaeva V. S. Zhurnal M. M. i F. M. Dostoevskikh «Epokha» (1864-1865) [The Journal of Mikhail and Fedor Dostoevsky "Epokha" (1864-1865)]. Moscow, Nauka Publ., 1975. 303 p. (In Russ.)

19. Nechaeva V. S. Opisanie rukopisey F. M. Dostoevskogo [The Description of Fedor Dostoevsky's Manuscripts]. Moscow, The Academy of Sciences of the USSR Publ., 1957. 589 p. (In Russ.)

20. Ornatskaya T. I. Clarifications and Additions to the Commentary of the Complete Works of Dostoevsky. "The Siberian Notebook" Editorial Literary Circle of F. M. and M. M. Dostoevsky (1860-1865). In: Dostoevskiy. Materialy $i$ issledovaniya [Dostoevsky. Materials and Researches]. Leningrad, Nauka Publ., 1983, vol. 5, pp. 222-225. (In Russ.)

21. Rozenblyum L. M. Art Diaries by Fedor Dostoevsky. In: Neizdannyy Dostoevskiy: Zapisnye knizhki i tetradi 1860-1881 godov [The Unpublished Dostoevsky: Notebooks and Workbooks of 1860-1881]. Moscow, Nauka Publ., 1971, pp. 9-92. (Ser. "Literary Heritage"; vol. 83). (In Russ.)

22. Stepanyan K. The Gospel of John and the Novel "The Idiot". In: Dostoevskiy i mirovaya kul'tura. Al'manakh № 14 [Dostoevsky and World Culture. Almanac No. 14]. Moscow, Korneev S. T. Publ., 2001, pp. 96-111. (In Russ.)

23. Strakhov N. N. Memories of Fedor Mikhailovich Dostoevsky. In: Biografiya, pis'ma i zametki iz zapisnoy knizhki F. M. Dostoevskogo [Biography, Letters and Notes From the Notebook by Fedor Dostoevsky]. St. Petersburg, A. S. Suvorin's Printing House Publ., 1883, pp. 179-329. (In Russ.)

24. Fateev V. A. M. N. Katkov and N. N. Strakhov. The History of the Relationship of Two Dissimilar Thinkers. In: Russko-Vizantiyskiy vestnik [Russian-Byzantine Herald], 2019, no. 1 (2), pp. 177-203. Available at: https://readera.ru/140240260 (accessed on May 1, 2019). DOI: 10.24411/2588-0276-2019-10012 (In Russ.)

25. Fridlender G. M. New Materials from the Handwritten Heritage of the Artist and Publicist. In: Neizdannyy Dostoevskiy: Zapisnye knizhki i tetradi 1860-1881 godov [The Unpublished Dostoevsky: Notebooks and Workbooks of 1860-1881]. Moscow, Nauka Publ., 1971, pp. 93-122. (Ser. "Literary Heritage"; vol. 83). (In Russ.) 